\title{
Annonaa muricata Linn Leaf Induce Apoptosis in Cancer Cause Virus
}

\author{
Okid Parama Astirin ${ }^{1}$, Anief Nur Artanti ${ }^{1}$, Meutia Srikandi Fitria ${ }^{1}$, Eva Agustina Perwitasari ${ }^{1}$, \\ Adi Prayitno $^{2 *}$ \\ ${ }^{1}$ Department of Biology, Faculty of Mathematics and Natural Science, University of Sebelas Maret, Surakarta, Indonesia; ${ }^{2}$ Depart- \\ ment of Dental and Oral Disease, Faculty of Medicine, University of Sebelas Maret, Surakarta, Indonesia. \\ Email: *drgadiprayitno@yahoo.com
}

Received July $18^{\text {th }}$, 2013; revised August 20 ${ }^{\text {th }}$, 2013; accepted August $28^{\text {th }}, 2013$

Copyright (c) 2013 Okid Parama Astirin et al. This is an open access article distributed under the Creative Commons Attribution License, which permits unrestricted use, distribution, and reproduction in any medium, provided the original work is properly cited.

\begin{abstract}
Introduction: Now many studies conducted on the drug substance from nature that can serve as an anticancer agent as a potential chemoprevention agent, such as Annona muricata Linn leaf escort chemotherapy, which was flaring. The cancer cell in humans was included the loss of p53 protein function due to mutations in the protein gene. Other causes are that the p53 proteins are not functioning due to an increase in protein misfolding event chaperones and degradation events ubiquitous as binding by viral protein. Method: Cytotoxicity assay performed on 24 well plate micro-cultures. HeLa cells are as $2 \times 10^{4}$ cells in $100 \mathrm{~mL}$ in RPMI media. Created control is RPMI and solvent DMSO $0.25 \%$. Cytotoxic Test performed by the method of calculation tryphan blue dye exclusion. Being fasted for 24 hours in the culture medium, then the cells are grown in micro-plate with media plus samples with a non-lethal concentration (LC50) of partition and fractionation Annona muricata Linn leaf. Sampling is performed at 24 hours. Each of these wells is calculated the number of living cells and made the curve of cell number and incubation time. Result: The results showed that HeLa cells are being LC50 partition of leaves Annona muricata Linn in ethyl_acetate his cell death rate was higher (2000 $\mathrm{\mu g} / \mathrm{ml}$ have 131.89\%; $15.625 \mu \mathrm{g} / \mathrm{ml}$ have $11.37 \%$ ) and in ethanol-distillate water his cell death rate was lower (2000 $\mu \mathrm{g} / \mathrm{ml}$ have 35.80\%; $15.625 \mu \mathrm{g} / \mathrm{ml}$ have 3.97\%). Another results showed that HeLa cells are being LC50 fractionation of leaves Annona muricata Linn in chloroform his cell death rate was higher $(2000 \mu \mathrm{g} / \mathrm{ml}$ have 91.86\%; $15.625 \mu \mathrm{g} / \mathrm{ml}$ have 2.68\%) and in ethyl acetate, his cell death rate was lower $(2000 \mu \mathrm{g} / \mathrm{ml}$ have $23.79 \%$; $15.625 \mu \mathrm{g} / \mathrm{ml}$ have 4.69\%). Figure regression LC50 of HeLa cell culture treatment with partition or fractionation looks of regression test is the positive regression coefficient. Conclusion: Annona muricata Linn leaf in chloroform is a good candidate for chemoprevention escort chemotherapy for cancer causing viruses.
\end{abstract}

Keywords: Chemoprevention; Annona muricata Linn Leaf; HeLa Cell Culture; Apoptosis

\section{Introduction}

Many studies conducted on the drug substance from nature that can serve as an anticancer agent as a potential chemoprevention agent's escort chemotheraphy [1-4]. Many studies have shown the possibility of anti-cancer compounds that have toxicity selectively kill cancer cells without damaging normal cells, the compound derived from acid molecule from nature like fruit, e.g. with docking methods on the component of red fruit and tested for cancer therapy through modeling followed by moleculardynamics simulations $[5,6]$. The study on cytotoxic tests at the cellular level has been conducted, but very limited

"Corresponding author. testing on the molecular level, especially in cancers caused by viral infections. Now it is revealed that Annona muricata Linn members expressed empirically to fight cancer [7-9]. Are after being proven cellular and molecular leaf isolate tailings will produce bioproduct that can be used by the public as a potential chemoprevention agent's escort agency chemotheraphy?

Cancer is a disease that ranks second leading cause of death in the world. The usual approach to cancer prevention, among others by: prevention of interaction with cancer-causing agents, increasing defense mechanisms against cancer and lifestyle modifications. The main focus of this research is that cancer is caused by a viral infection i.e. cervical cancer (CC) is the number of events, it is 
quite high in Indonesia is quite high. Cervical Cancer is due to a viral infection known as the Human papilloma virus (HPV). World prevalence rate HPV infection is $99.7 \%$ of the CC [10-12]. Cancer begins with a scene gene expression imbalance specific role in apoptosis and cell proliferation, and DNA repair [13]. Understanding these processes provides the basis for chemotherapy apoptosis through induction of cancer cell death $[7,14$, 15]. The process of apoptosis can occur through multiple pathways. One point that has close links with cancer through the induction of apoptosis is much played by p53 protein [16-18]. Failure of apoptosis regulation is the key principle to the success of carcinogenesis, i.e. inhibition of apoptosis events $[19,20]$. When the high incidence of the CC in developing countries, including Indonesia, is not addressed, it will have an impact on the rate of increase in morbidity and higher mortality, and at last will reduce the quantity and quality of human resources.

The flow of thought between chemoprevention Annona muricata Linn, and the incidence of apoptosis in virus CC can be explained by the flow of the discussion pathobiology [21,22]. Expected to chemoprevention bioproduct Annona muricata Linn leaf as Annonaceae members can be deadly virus, which means lower stressor dynamics and increase of the expression of p53, so that events can be enhanced by apoptosis [7,14,15,23,24].

Many stressors, such as hotness, spiciness, wounds and infections, cause or trigger the expression of specific gene. Cells infected with the virus will experience distress increases, and the expression of p53 protein, among others aims to enhance apoptosis. The expression of p53 protein is a form of cell response to a stressor [25-27]. However, these efforts do not always succeed, even progress to cancer. Decreased expression of the p53 protein can cause a decrease in cell apoptosis mechanism. Protein p53, Baxxl, caspase-3 is known as an inhibitor of cancer and is a protein that plays an important role in the regulation of apoptosis. Decrease in apoptotic cells that are not able to offset the increase in cell proliferation would result in the occurrence of cancer cells [28]. Cause of p53 malfunction is clear that the control system as chaperone as plays an important role if the folding process fails or an error occurs, causing folding abnormalities and targeted functionality to accumulate. The accumulation of faulty protein folding would harm cells and can result in apoptosis. Many data have shown, how chaperones facilitate transformation towards cancer at molecular level, and support the concept that "there are events of protein function changes in carcinogenesis, which needs serious attention in the development of human cancers" $[20,29]$. Another cause of p53 malfunction is mutation so the p53 proteins don't act optimally. Approximately 50\% of human cancer cells lose p53 function due to mutations in the protein-coding gene [30,31]. Records of other cause are that E6 protein of HPV-16 and 18 will result in the inactivation of the p53 gene product through binding mechanism called the ubiquitin-dependent proteolytic pathway (E6AP), resulting in decreased levels of p53 protein (wild-type) [32]. Returning a mutated p53 function could potentially trigger a mass apoptosis, which can kill cancer cells effectively and prove that Actinomycin D (chemotherapy drug) affects implantation failure of Rattus norvegicus [33]. All were expected to explain the role of Annona muricata Linn leaves in decreasing infected virus and increasing expression of p53 protein in the event CC patients infected with the HPV through increased apoptosis.

\section{Material and Method}

HeLa cells were grown in culture bowls containing RPMI 1640 medium and FBS added 0.5\%, Penstrep 2\% and fungizon $0.5 \%$ and incubated in a $5 \% \mathrm{CO}_{2}$ incubator for 24 hours. The cells density is $2 \times 10^{4}$ cells $/ \mathrm{ml}$.

Extraction using two methods, namely an extraction method using $96 \%$ ethanol and percolation method using the solvent n-hexane, chloroform, ethyl acetate, and ethanol 96\%.Results of maceration partitioned using solvents n-hexane, chloroform, ethyl acetate, and ethanol-distillate water. Active extract of the results of the percolation fractionated using vacuum liquid chromatography (VLC) with a mobile phase n-hexane and ethyl acetate, as well as the stationary phase silica gel 60 PF 254.

The stage to develop the test cells HeLa is by Freshney and Gadek method with some modification [34,35]. Cytotoxicity assay performed on 24 well plate micro-cultures. HeLa cells as $2 \times 10^{4}$ cells in $100 \mathrm{~mL}$ RPMI media. Further isolates were given $100 \mathrm{~mL}$ at a concentration series ranking triplet. Created are RPMI for medium control and solvent DMSO 0.25\%. Cytotoxic Test performed by the method of calculation tryphan blue dye exclusion (MTT). Cells were grown for 24 hours in the culture medium. The cells were grown in micro-plate with media plus samples with a non-lethal concentration (LC50 below) of partition or fractionation Annona muricata Linn leaf. Sampling performed at 24 hours.

Each of these wells is calculated the number of living cells. The percentage of cell death was calculated using the modified formula Abbot [36]. Thus made curve for the number of cells death again incubation time [37].

\section{Result}

The results showed (Figure 1 and Table 1) that HeLa cells are being LC50 partition of leaves Annona muricata Linn in ethyl acetate his cell death (apoptotic) rate was higher (2000 $\mu \mathrm{g} / \mathrm{ml}$ have 131.89\%; $15.625 \mu \mathrm{g} / \mathrm{ml}$ have $11.37 \%)$ and in ethanol-distillate water his cell death (apoptotic) rate was lower (2000 $\mu \mathrm{g} / \mathrm{ml}$ have 35.80\%; $15.625 \mu \mathrm{g} / \mathrm{ml}$ have $3.97 \%$ ) 


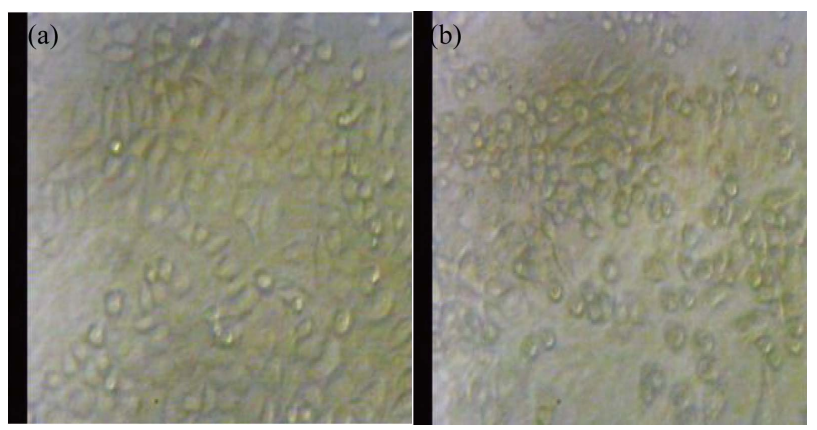

Figure1. (a) Hela cells culture treatment with DMSO as a control (cell death/apoptotic rate: $\mathbf{3 . 8 0 \% ) ; ~ ( b ) ~ H e l a ~ c e l l s ~ c u l - ~}$ ture after treatment with partition of leaves Annona muricata Linn in chloroform (cell death/apoptotic rate: $65.20 \%$ ).

Table1. The average percentage of death cells associated with many concentration and many solvent from partition the leaves Annona muricata Linn. We can look that partition of leaves Annona muricata Linn in solvent ethyl acetate make cell death/apoptotic rate is higher than other (average percentage is $131.89 \%$ cells death in $2000.00 \mu \mathrm{g} / \mathrm{ml}$ and $11.37 \%$ death cells in $15.62 \mu \mathrm{g} / \mathrm{ml}$ concentration) but in chloroform cell death/apoptotic rate is number 3 (average percentage $65.20 \%$ death cells in $2000.00 \mu \mathrm{g} / \mathrm{ml}$ and $18.42 \%$ death cells in $15.62 \mu \mathrm{g} / \mathrm{ml}$ concentration).

\begin{tabular}{lccc}
\hline No. & Solvent & $\begin{array}{c}\text { Concentration } \\
(\mu \mathrm{g} / \mathrm{ml})\end{array}$ & $\begin{array}{c}\text { Average percentage } \\
\text { of death cells }(\%)\end{array}$ \\
\hline \multirow{2}{*}{ 1. } & Ethyl & a) 2000.00 & 131.89 \\
& acetate & b) 15.62 & 11.37 \\
2. & n-heksan & a) 2000.00 & 106.53 \\
& & b) 15.62 & 21.41 \\
3. & Chloroform & a) 2000.00 & 65.20 \\
& & b) 15.62 & 18.42 \\
4. & Ethanol distillate & a) 2000.00 & 35.80 \\
& water & b) 15.62 & 3.97 \\
\hline
\end{tabular}

Figure regression LC50 of HeLa cell culture treatment with the partition shown below in Figures 2(a)-(d). From the looks of regression test is the positive regression coefficient. This value is LC50 of four-kind partition Annona muricata Linn leaves of HeLa cells incubated for 24 hours.

Another results showed (Figure 3 and Table 2) that HeLa cells are being LC50 fractionation in chloroform his cell death (apoptotic) rate was higher $(2000 \mu \mathrm{g} / \mathrm{ml}$ have $91.86 \% ; 15.625 \mu \mathrm{g} / \mathrm{ml}$ have $2.68 \%$ ) and in ethyl acetate his cell death (apoptotic) rate was lower (2000 $\mu \mathrm{g} / \mathrm{ml}$ have $23.79 \%$; $15.625 \mu \mathrm{g} / \mathrm{ml}$ have $4.69 \%$ ).

Figure regression LC50 of HeLa cell culture treatment with the fractionation shown below in Figures 4(a)-(d)). From the looks of regression test is the positive regression coefficient. This value is LC50 of four-kind fractionation Annona muricata Linn leaves of HeLa cells incubated for 24 hours.

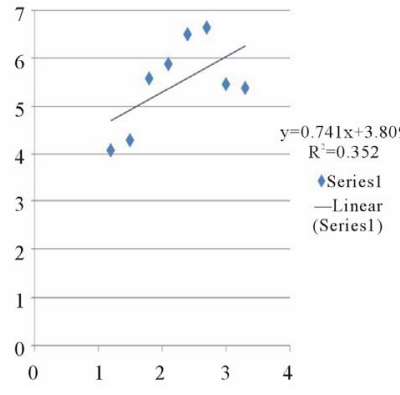

(a)

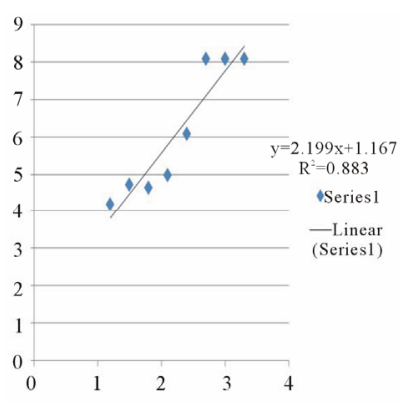

(c)

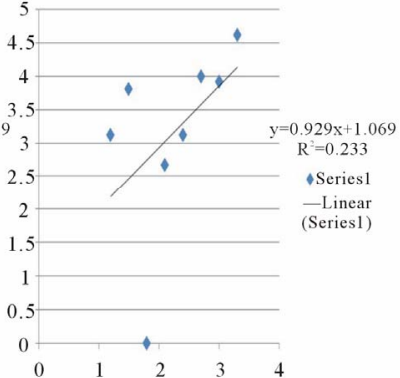

(b)

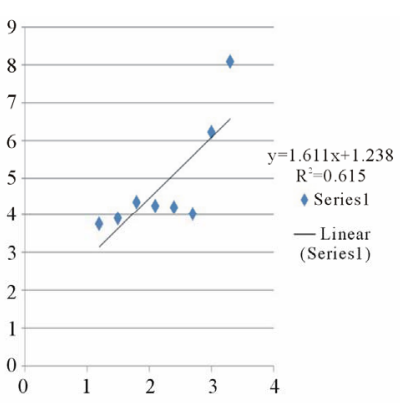

(d)
Figure 2. The curve of (a) Partition Annona muricata Linn leaves in chloroform; (b) Partition Annona muricata Linn leaves in ethanol-distillate water; (c) Partition Annona muricata Linn leaves in n-heksan; (d) Partition Annona muricata Linn leaves in ethyl acetate.

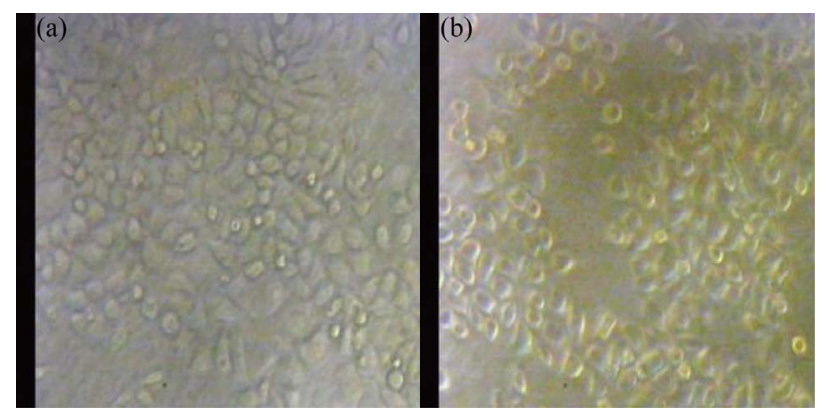

Figure 3. (a) HeLa cell culture treatment with DMSO as a control (cell death/apoptotic rate: $3.80 \%$ ); (b) HeLa cell culture after treatment with fractionation of leaves Annona muricata Linn in chloroform (cell death/apoptotic rate: 91.86\%).

\section{Discussion}

The incidence of cancer associated with: First, there is increased expression or mutation of gene trigger cancer. Second, there is a decrease in the expression or mutation of gene cancer suppressor. Cancer suppressor gene is normal gene that has an important function in cell homeostasis. If that gene don't work, then implicated for occur of cancer. Third, the gene associated with cancer is the presence of DNA-repair enzymes. Changes in the function of these enzymes will lead to the occurrence of cancer. Fourth, the process of apoptosis is not normal, 
Table 2. The average percentage of death cells associated with many concentration and many solvent from fractionation the leaves Annona muricata Linn. We can look that fractionation of leaves Annona muricata Linn in solvent chloroform cell death/apoptotic rate is higher than other (average percentage is $91.86 \%$ death cells in $2000.00 \mu \mathrm{g} / \mathrm{ml}$ and $2.68 \%$ death cells in $15.62 \mu \mathrm{g} / \mathrm{ml}$ concentration) but in solvent ethyl acetate cell death/apoptotic rate is lower that other (average percentage is $\mathbf{2 3 . 7 9 \%}$ death cells in $\mathbf{2 0 0 0 . 0 0}$ $\mu \mathrm{g} / \mathrm{ml}$ and $4.69 \%$ in $15.62 \mu \mathrm{g} / \mathrm{ml}$ concentration).

\begin{tabular}{lccc}
\hline No. & Solvent & $\begin{array}{c}\text { Concentration } \\
(\mu \mathrm{g} / \mathrm{ml})\end{array}$ & $\begin{array}{c}\text { Average percentage } \\
\text { of death cells (\%) }\end{array}$ \\
\hline 1. & Chloroform & a) 2000.00 & 91.86 \\
& & b) 15.62 & 2.68 \\
2. & n-heksan & a) 2000.00 & 75.36 \\
& & b) 15.62 & 8.34 \\
3. & Ethanol distillate & a) 2000.00 & 34.77 \\
& water & b) 15.62 & 3.44 \\
4. & Ethyl acetate & a) 2000.00 & 23.79 \\
\hline
\end{tabular}

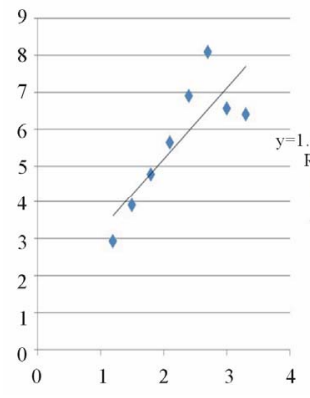

(a)

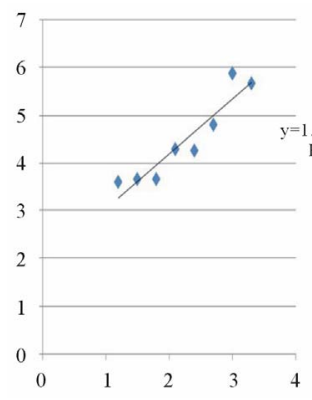

(c)

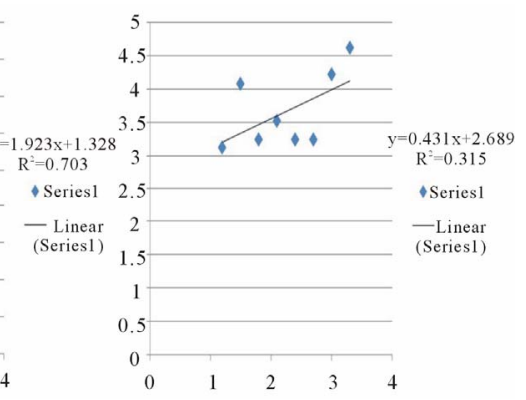

(b)

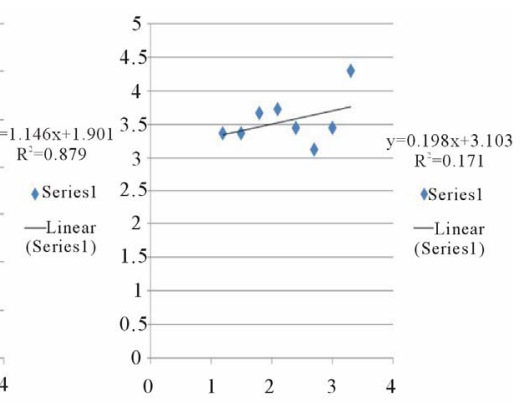

(d)
Figure 4. The curve of (a) Fractionation Annona muricata Linn leaves in chloroform; (b) Fractionation Annona muricata Linn leaves in ethanol-distillate water; (c) Fractionation Annona muricata Linn leaves in n-heksan; (d) Fractionation Annona muricata Linn leaves in ethyl acetate.

that happen inhibition of apoptosis [13,16-18,38]. Further developments on the definition of cancer has been suggested that incidence of cancer begins in the disorder at the level of epigenetic (methylation and/or histone modi- fication) and continues to change at the level of genetic (mutation) [39].

Cell distress by stressor HPV show an increase in the expression of protein chaperones (Hsp70 and Hsp40). Imbalance between increased levels of Hsp70 and Hsp40 with decreased ATP production by the mitochondria so made possible for error events of protein folding of protein denatured or protein newly translated, so that the protein can't function normally. Abnormal function of these proteins results in the inhibition of apoptosis and increased cell proliferation that triggers carcinogenesis $[29,40]$. In the state of distress caused by HPV, the cells will express Hsp for the purpose of homeostasis, an imbalance will develop into cancer [41,42].

Various compounds present in Annonaceae familia, including potential anti-cancer compounds. Three compounds in Annona muricata Linn a potential anti-cancer namely are monotetrahydrofuran acetogenins, muricin $\mathrm{H}$, muricin I, and cis-annomontacin [43]. Acetogenin compounds (squamocin A, B, C, and D) and annotemoyin-1 and -2 the Annonaceae have cytotoxic effects [44], platelet agregation inhibitor [45], inhibitor of HIV replication [46], antidiabetic agents (antihiperglikemik) and antioxidants [47,48], pesticide [49], and can be used in the treatment of Neisseria gonorrhea [50]. Squamocin serves as insecticides, while the ascimicin have an antileukemia effect [51]. Caryophyllene oxide on the bark has analgesic and anti-inflammatory activity [52], and cyclosquamosin D on seed proved showed inhibition of proinflammatory cytokines in macrophages [45]. Further treatment of cancer with natural ingredients is not always the specific target. Anti-cancer herbal remedies white turmeric (Curcuma zedoaria) affects organs such as the always do mitosis ovarian follicles in mice [53]. Acetogenin the Annonaceae are composed of fatty acids C32 or C34 long chain fatty acids. Bioactivity acetogenin was diverse as anticancer, immunosuppressive, pesticide, antiprotozoal, and antimicrobial. Acetogenin wall membrane inhibited mitochondrial ATP production, resulting in the production of energy in cancer cells and stops cancer cells eventually die [54]. Acetogenin was very selective, only attacks cancer cells that have excess ATP. These compounds do not attack other cells are normal in the body, disrupting the circulation of cancer cells by reducing the amount of ATP [55]. Soursop leaf cell-killing colon cancer cells to 10,000 times stronger than Adriamycin and other chemotherapy. Some derivatives in different types of structures and some isomers showed significant selectivity cancer cell line, for example, the fight against prostate cancer (PC-3). The main mode of action is acetogenin inhibitor of NADH: oxidoreductase uniquinone, the enzyme complex is important in oxidative phosphorylation in the mitochondria and inhibits NADH oxidase uniquinone the plasma membrane of cancer cells [56]. 


\section{Conclusion}

Annona muricata Linn leaf in chloroform is a good cadidate for chemoprevention escort chemotherapy for cancer cause virus.

\section{Acknowledgements}

We thank to acknowledge Higher Education Competitive Research Project Ministry of Education and Culture Republic of Indonesia for Grand Featured Research Universities 2013, LPPT of Gajah Mada University and special thanks to acknowledge, Prof Dr Rafik Karsidi, MSc as a rector of Sebelas Maret University Surakarta Indonesia, Prof Ir Ari Handoko Ramelan, MSc (Hons), PhD as a dean of Faculty of Mathematics and Natural Science of Sebelas Maret University Surakarta Indonesia and thanks to acknowledge Prof Dr Suhartono Taat Putra MS for much inspirations to wrote this article.

\section{REFERENCES}

[1] G. W. Chang, M. S. H. Wahyuningsih and A. A. A. Yustina, "Effect of Benalu (Dendrophtoe sp.) Leaves Extract on the Male Rat (Rattus Norvegicus) Benzidine Induced Hepatotoxicity,” Journal Kedokteran Yarsi, Vol. 7, No. 1. 1999, pp. 121-132.

[2] D. J. Greenblatt and L. L. von Moltke, "Interaction of Warfarin with Drugs, Natural Substances, and Foods," Journal of Clinical Pharmacology, Vol. 45, No. 2, 2005, pp. 127-132. doi:10.1177/0091270004271404

[3] P. Imming, "Molecular Targets of Natural Drug Substances: Idiosyncrasies and Preferences,” Planta Medica, Vol. 76, No. 16, 2010, pp. 1794-1801. doi:10.1055/s-0030-1250236

[4] T. Shan, Q. Ma, K. Guo, J. Liu, W. Li, F. Wang and E. $\mathrm{Wu}$, "Xanthones from Mangosteen Extracts as Natural Chemopreventive Agents: Potential Anticancer Drugs," Current Molecular Medicine, Vol. 11, No. 8, 2011, pp. 666-677.

[5] K. H. Lee, “Anticancer Drug Design Based on PlantDerived Natural Products," Journal of Biomedical Science, Vol. 6, No. 4, 1999, pp. 236-250.

[6] H. Harada, U. Yamashita, H. Kurihara, E. Fukushi, J. Kawabata and Y. Mamei, "Antitumor Activity of Palmitic Acid Found as a Selective Cytotoxic Substance in a Marine Red Alga," Anticancer Research, Vol. 22, No. 5, 2002, pp. 2587-2590.

[7] B. V. Pardhasaradhi, M. Reddy, A. M. Ali, A. L. Kumari and A. Khar, "Differential Cytotoxic Effects of Annona Squamosa Seed Extracts on Human Tumour Cell Lines: Role of Reactive Oxygen Species and Glutathione," Journal Biosciences, Vol. 30, No. 2, 2005, pp. 237-244. doi:10.1007/BF02703704

[8] M. Trubus, "Daun Sirsak vs Chemotherapy (Kanker),” Laporan Utama Majalah Trubus, 2011

[9] A. S. N. Formagio, C. A. L. Kassuya, F. F. Neto, C. R. F. Volobuff, E. K. K. Iriguchi, M. do C. Vieira and M. A.
Foglio, "The Flavonoid Content and Antiproliferative, Hypoglycaemic, Anti-Inflammatory and Free Radical Scavenging Activities of Annona dioica St. Hill,” BMC Complementary and Alternative Medicine, Vol. 13, 2013, p. 14. doi:10.1186/1472-6882-13-14

[10] L. Teppo, E. Pukkala and E. Saxen, "Multiple CancerAn Epidemiologic Exercise in Finland,” Journal of $\mathrm{Na}$ tional Cancer Institute, Vol. 75, No. 2, 1985, pp. 207217.

[11] A. Prayitno, "Cervical Cancer with Human Papilloma Virus and Epstein Barr Virus Positif," BMC Journal of Carcinogenesis, Vol. 5, 2006, p. 13. doi:10.1186/1477-3163-5-13

[12] D. Subramanya and P. D. Grivas, "HPV and Cervical Cancer: Updates on an Established Relationship," Postgraduate Medicine, Vol. 120, No. 4, 2008, pp. 7-13. doi:10.3810/pgm.2008.11.1928

[13] J. Samer, Sharkaphaviova, S. Miluska and G. Diana, "Analysis of P53 Status in Human Cell Line Using a Functional Assay in Yeast: Detection of New No Sense p53 Mutattion in Codon 124,” Oncology Report, Vol. 14. 2005, pp. 901-907.

[14] H. F. Chiu, T. T. Chih, Y. M. Hsian, C. H. Tseng, M. J. $\mathrm{Wu}$ and Y. C. Wu, "Bullatacin, a Potent Antitumor Annonaceous Acetogenin, Induces Apoptosis through a Reduction of Intracellular cAMP and cGMP Levels in Human Hepatoma 2.2.15 Cells,” Biochemical Pharmacology, Vol. 65, No. 3, 2003, pp. 319-327. doi:10.1016/S0006-2952(02)01554-X

[15] G. Jiebin, O. Hirokazu, O. Shigeki, N. Shinobu and N. Shinji, “Arsenic Trioride Induces Apoptosis in Leukemia and Lymphoma Cell Lines via the CD95/CD95L System,” Oncology Reports, Vol. 10, 2005, pp. 705-709.

[16] S. Haupt, M. Berger, Z. Goldberg and Y. Haupt, "Apoptosis-The p53 Network,” Journal Cell Science, Vol. 116, No. 20, 2003, pp. 4077-4085. doi:10.1242/jcs.00739

[17] A. Vazquez, E. E. Bond, A. J. Levine and G. L. Bond, "The Genetics of the p53 Pathway, Apoptosis and Cancer Therapy," Nature Review. Drug Discovery, Vol. 7, No. 12, 2008, pp. 979-987. doi:10.1038/nrd2656

[18] J. D. Amaral, J. M. Xavier, C. J. Steer and C. M. Rodrigues, "The Role of p53 in Apoptosis," Discovery Medicine, Vol. 9, No. 45, 2010, pp. 145-152.

[19] R. S. Fife, B. T. Rougraff, C. Proctor and G. W. Sledge Jr., "Inhibition of Proliferation and Induction of Apoptosis by Doxycycline in Cultured Human Osteosarcoma Cells,” Journal of Laboratory and Clinical Medicine, Vol. 130, No. 5, 1997, pp. 530-534. doi:10.1016/S0022-2143(97)90130-X

[20] M. P. Mayer and B. Bukau, "Hsp70 Chaperones: Cellular Functions and Molecular Mechanism," Cellular and Molecular Life Sciences, Vol. 62, No. 6, 2005, pp. 670-684. doi:10.1016/S0022-2143(97)90130-X

[21] C. R. Young and C. J. Welsh, "Stress, Health, and Disease,” Cell Science, Vol. 2, No. 2, 2005, pp. 132-159.

[22] E. H. Vogel, M. E. Castro, P. A. Solar and F. A. Soto, "Enhancement of Pavlovian Conditioned Immunosupression in Rats," Acta Neurobiologiae Experimentalis, Vol. 
67, No. 1, 2007, pp. 71-81.

[23] Y. P. Zhang and Y. Xiong, “A p53 Aminoterminal Nuclear Export Signal Inhibited by DNA Damage-Induced Phosphorylation,” Science, Vol. 292, No. 5523, 2001, pp. 1910-1915. doi:10.1126/science.1058637

[24] Y. H. Zhang, H. Y. Peng, G. H. Xia, M. Y. Wang and Y. Han, "Anticancer Effect of Two Diterpenoid Compounds Isolated from Annona glabra Linn,” Acta Pharmacology Singapore, Vol. 25, No. 7, 2004, pp. 937-942.

[25] W. B. Derry, A. P. Putzke and J. H. Rothman, "Caenorhabditis Elegans p53: Role in Apoptosis, Meiosis, and Stress Resistance,” Science, Vol. 294, No. 5542, 2001, pp. 591-595. doi:10.1126/science.1065486

[26] L. Qu, S. Huang, D. Baltzis, A. M. Rivas-Estilla, O. Pluquet, M. Hatzoglou, C. Koumenis, Y. Taya, A. Yoshimura and A. E. Koromilas, "Endoplasmic Reticulum Stress Induces p53 Cytoplasmic Localization and Prevents p53-Dependent Apoptosis by a Pathway Involving Glycogen Synthase Kinase-3beta," Genes and Development, Vol. 18, No. 3, 2004, pp. 261-277. doi:10.1101/gad.1165804

[27] J. L. Alberto, M. D. Macario and E. C. de Macario, "Sick Chaperones, Cellular Stress, and Disease,” New England Journal of Medicine, Vol. 353, No. 14, 2005, pp. 14891501. doi:10.1056/NEJMra050111

[28] I. M. Ghobrial, T. E. Witzig and A. A. Adjei, "Targeting Apoptosis Pathways in Cancer Therapy," CA: A Cancer Journal for Clinicians, Vol. 55, No. 3, 2005, pp. 178-194.

[29] A. Prayitno, E. Asnar, O. P. Astirin, D. Rosmala and S. T. Putra, "Heat Shock Protein 40 (Hsp40) and Hsp70 Protein Expression in Oral Squamous Cell Carcinoma (OSCC)," Journal of Cancer Therapy, Vol. 4, No. 3, 2013, pp. 734-741. doi:10.4236/jct.2013.43090

[30] M. Hollstein, D. Sidransky, B. Vogelstein and C. C. Harris, "p53 Mutations in Human Cancers," Science, Vol. 253, No. 5015, 1991, pp. 49-53.

[31] T. Soussi and G. Lozano, "p53 Mutation Heterogeneity in Cancer," Biochemical Biophysical Research Communications, Vol. 331, No. 3, 2005, pp. 834-842. doi:10.1016/j.bbrc.2005.03.190

[32] A. Prayitno, R. Darmawan, I. Yuliadi and A. Mudigdo, "The Expression of p53, Rb, and c-myc Protein in Cervical Cancer by Immunohistochemistry Stain,” Biodiversitas, Vol. 6, No. 3, 2005, pp. 157-159.

[33] O. P. Astirin, "Implantasi Pada Rattus Norvegicus Setelah Perlakuan Dengan Actinomycin D," Thesis, Faculty of Pasca Sarjana, University of Gajah Mada, Yogyakarta, 1991.

[34] F. R. Ian, "Culture of Animal Cells: A Manual of Basic Techniques,” 4th Edition, Wiley-Lies, Canada, 2000.

[35] Gadek, J. Wesierska, V. Kotala, S. Kuchtickova and M. D. Horky, "Induction of Apoptosis in Human Cervic Carcinoma Cells During Therapy by Cisplatin,” International Symposium on Predictive Oncology and Intervention Strategies, Paris, 9-12 February 2002.

[36] B. N. Meyer, N. R. Ferriqni, J. E. Putnam, L. B. Jacobsen, D. E. Nichols and J. L. McLaughlin, "Brine Shrimp: A Convenient General Bioassay for Active Plant Consti- tuents,” Planta Medicine, Vol. 45, No. 5, 1982, pp. 31-34. doi:10.1055/s-2007-971236

[37] Mursyidi and Achmad, "Statistika Farmasi Dan Biologi," Ghalia, 1985.

[38] N. E. Raab-Traub, "Epstein-Barr Virus in the Pathogenesis of NPC,” Seminars in Cancer Biology, Vol. 12, No. 6, 2002, pp. 431-441. doi:10.1016/S1044579X0200086X

[39] A. P. Feinberg, R. Ohlsson and S. Henikoff, "The Epigenetic Progenitor Origin of Human Cancer,” Nature Reviews. Genetics, Vol. 7, No. 1, 2006, pp. 21-33. doi:10.1038/nrg1748

[40] J. L. Alberto, M. D. Macario and E. C. de Macario, "Sick Chaperones, Cellular Stress, and Disease," The England Journal of Medicine, Vol. 353, No. 14, 2005, pp. 14891501.

[41] C. Jolly and R. I. Morimoto, "Role of the Heat Shock Response and Molecular Chaperones in Oncogenesis and Cell Death,” Journal of the National Cancer Institute, Vol. 92, No. 19, 2000, pp. 1564-1572. doi:10.1093/jnci/92.19.1564

[42] J. Villar, "Heat Shock Protein Gene Expression and Survival in Critical Illness," Critical Care, Vol. 4, 2000, pp. 2-5. doi:10.1186/cc643

[43] C. C. Liaw, F.-R. Chang, C.-Y. Lin, C.-J. Chou, H.-F. Chiu, M.-J. Wu and Y.-C. Wu, "New Cytotoxic Monotetrahydrofuran Annonaceous Acetogenins from Annona muricata," Journal of Natural Products, Vol. 65, No. 4, 2002, pp. 470-475. doi:10.1021/np0105578

[44] H. J. Yang, X. Li, N. Zhang, J. W. Chen and M. Y. Wang, "Two New Cytotoxic Acetogenins from Annona squamosa,” Journal of Asian Natural Products Research, Vol. 11, No. 3, 2009, pp. 250-256. doi:10.1080/10286020802682916

[45] Y. L. Yang, K. F. Hua, P. H. Chuang, S. H. Wu, K. Y. Wu, F. R. Chang and Y. C. Wu, "New Cyclic Peptides from the Seeds of Annona squamosa L. and Their AntiInflammatory Activities," Journal of Agricultural and Food Chemistry, Vol. 56, No. 2, 2008, pp. 386-392. doi:10.1021/jf072594w

[46] Y. C. Wu, Y. C. Hung, F. R. Chang, M. Cosentino, H. K. Wang and K. H. Lee, "Identification of ent-16 beta, 17-Dihydroxykauran-19-oic Acid as an Anti-HIV Principle and Isolation of the New Diterpenoids Annosquamosins A and B from Annona squamosa," Journal of Natural Products, Vol. 59, No. 6, 1996, pp. 635-671. doi:10.1021/np960416j

[47] M. Kaleem, M. Asif, Q. U. Ahmed and B. Bano, "Antidiabetic and Antioxidant Activity of Annona squamosa Extract in Streptozotocin-Induced Diabetic Rats," Singapore Medicine Journal, Vol. 47, No. 8, 2006, pp. 670675.

[48] S. Panda and A. Kar, "Antidiabetic and Antioxidative Effects of Annona squamosa Leaves Are Possibly Mediated through Quercetin-3-O-Glucoside,” BioFactors, Vol. 31, No. 3-4, 2007, pp. 201-210.

[49] A. Jaswanth, P. Ramanathan and K. Ruckmani, "Evaluation of Mosquitocidal Activity of Annona squamosa Leaves against Filarial Vector Mosquito, Culex quinque- 
fasciatus Say,” Indian Journal of Experimental Biology, Vol. 40, No. 3, 2002, pp. 363-365.

[50] P. Shokeen, K. Ray, M. Bala and V. Tandon, "Preliminary Studies on Activity of Ocimum sanctum, Drynaria quercifolia, and Annona squamosa against Neisseria gonorrhoeae," Sexually Transmitted Diseases, Vol. 32, No. 2, 2005, pp. 106-111. doi:10.1097/01.olq.0000152821.23777.90

[51] P. J. Schupp, C. Kohlert-Schupp, S. Whitefield, A. Engemann, S. Rohde, T. Hemscheidt, J. M. Pezzuto, T. P. Kondratyuk, E.-J. Park, L. Marler, B. Rostama and A. D. Wright, "Cancer Chemopreventive and Anticancer Evaluation of Extracts and Fractions from Marine Macro- and Micro-Organisms Collected from Twilight Zone Waters Around Guam," Natural Product Communications, Vol. 4, No. 12, 2009, pp. 1717-1728.

[52] M. J. Chavan, P. S. Wakte and D. B. Shinde, “Analgesic and Anti-Inflammatory Activity of Caryophyllene oxide from Annona squamosa L. Bark,” Phytomedicine, Vol. 17, No. 2, 2010, pp. 149-151. doi:10.1016/j.phymed.2009.05.016

[53] R. Lobo, K. S. Prabhu, A. Shirwaikar and A. Shirwaikar, "Curcuma zedoaria Rosc. (White Turmeric): A Review of Its Chemical, Pharmacological and Ethnomedicinal Properties," Journal of Pharmacy and Pharmacology, Vol. 61, No. 1, 2009, pp. 13-21.

[54] Z. Jiang, R.-Y. Chen, Y. Chen and D.-Q. Yu, “Donnaienin, a New Acetogenin Bearing a Hydroxylated Tetrahydrofuran Ring,” Journal of Natural Products, Vol. 61, No. 1, 1998, pp. 86-88. doi:10.1021/np9703196

[55] W. Anne-Isabelle, R. Hocquemiller, A. Laurens and A. Cavé, "Glaucafilin, an Acetogenin from Annona glauca," Journal of Phytochemistry, Vol. 44, No. 8, 1997, pp. 1537-1540.

[56] M. J. Rieser, Z. M. Gu, X. P. Fang, L. Zeng, K. V. Wood and J. L. McLaughlin, "Five Novel Mono-Tetrahydrofuran Ring Acetogenins from the Seeds of Annona muricata,” Journal of Natural Products, Vol. 59, No. 2, 1996, pp. 100-108. doi:10.1021/np960037q 